\title{
La abducción según Peirce: Reflexiones desde el Sur sobre la crisis de representación desencadenada por el COVID-19
}

\author{
Abduction According to Peirce: Reflections from the South \\ on the Crisis of Representation Brought on by COVID-19
}

Paulina Aroch Fugellie ${ }^{I}$

Fecha de recepción: 8 de abril de 2021

Fecha de aceptación: 27 de mayo de 2021 


\section{Resumen}

En este artículo reflexiono acerca de la importancia del pensamiento abductivo en procesos de reinvención material y conceptual en el contexto de la actual crisis sanitaria. Inscrita en el cambio climático planetario, esta crisis sentaría las bases para una revolución semiótica. Por ello, interrogo el trabajo de Peirce sin perder consciencia de mi propio lugar y tiempo de interlocución. El COVID-19 trajo consigo una crisis de representación que, a diferencia de aquella que desencadenaron el Holocausto y la Segunda Guerra Mundial, y a la que la Escuela de Frankfurt respondió, demanda respuestas desde el Sur Global. Partiendo del llamado de Dussel a la defensa de la vida como urgencia ética ante su irresponsable cosificación en la modernidad capitalista colonial -la cual podría decirse desencadenó la pandemiabusco trazar un "mapa nocturno" que registre la actual crisis de sentido y permita reimaginar y rehacer el mundo, desde otro lugar.

Palabras clave: teoría crítica, interdisciplina, Sur Global, crisis de representación, COVID-19.

\section{Abstract}

In this article, I reflect on the importance of abductive thinking for processes of material and conceptual reinvention in the context of the current public health crisis. Inseparable from the climate change engulfing the planet, this crisis provides the basis for a semiotic revolution. Therefore, I interrogate Peirce's work without losing the sight of my own time and place of interlocution. COVID-19 has brought with it a crisis of representation which, in contrast to that unleashed by the Holocaust and World War II, and to which the Frankfurt School responded, demands responses from the Global South. Beginning from Dussel's call to defend life as a matter of ethical urgency in the face of its irresponsible objectification within colonial capitalist modernity - which arguably triggered the pandemic-, I trace a "nocturnal map"

that registers the present meaning-making crisis, and allows for a reimagining and remaking of the world from elsewhere.

Keywords: critical theory, interdisciplinarity, Global South, crisis of representation, COVID-19. 


\section{Introducción}

$\mathrm{L}$

a presente crisis sanitaria, inscrita en el cambio climático, ha llevado a una crisis de sentido y, de este modo, sienta las bases para una revolución semiótica, para un cambio paradigmático. Dado lo anterior, quiero reflexionar sobre la importancia del pensamiento abductivo en procesos de reinvención material y conceptual de nuestro mundo en la actualidad. A lo largo de este artículo, interrogaré el trabajo de Charles Sanders Peirce como cartógrafo e investigador en semiótica, con especial énfasis en su concepto de "abducción". El concepto de abducción resulta sumamente pertinente para un contexto, como el actual, en el cual se derrumba el piso de varias de nuestras formas de vida y creencias coligadas sostenidas hasta ahora y que nos daban cierta estabilidad, haciéndose urgente la necesidad de herramientas para construir nuevos horizontes.

De tal manera, mi propósito al recurrir a Peirce no es en modo alguno explicar la situación actual ni justificar mi entendimiento de la misma como desencadenada por el capitalismo colonial. Eso sería un absurdo. La inscripción de la actual crisis sanitaria en el cambio climático ha sido ampliamente investigada y argumentada por otros, siendo la postura que sostiene, por ejemplo, la directora de Salud Pública de la Organización Mundial de la Salud (OMS), María Neira. ${ }^{2}$ En el ámbito académico, Toby Miller ha llevado a cabo un exhaustivo y amplio análisis de dicha inscripción en el contexto del capitalismo colonial como detonante del cambio climático (véase 2021). Y, desde luego, el propio Enrique Dussel, a quien recurro en este artículo de manera constante, ha llevado a cabo un examen sistemático para llegar a conclusiones similares (véase 2020a y 2020b). Aquí no argumentaré dicha postura, sino que partiré de ella, en base a las investigaciones de los autores antes citados y de otros tales como Slavoj Žižek (2020), Judith Butler (2020), Byung-Chul Han (2020), David Harvey (2020), María Galindo (2020), Markus Gabriel (2020), Franco "Bifo" Berardi (2020), Fabio Seleme (2020), Rodrigo Karmy Bolton (2020), Maurizio Lazzarato (2020) y Arundhati Roy (2020), quienes sostienen y profundizan distintos aspectos de la correlación a la que yo refiero entre COVID-19 y capitalismo colonial. A partir de esta investigación ya realizada, yo decido centrarme no en discutir la causalidad del COVID-19, sino en reflexionar sobre sus consecuencias en el ámbito de la producción de sentido, en cómo la pandemia llegó a sacudir nuestra concepción estabilizada del mundo y cómo nos abre la posibilidad de construir otros nuevos.

Y es aquí donde entra en escena Peirce, como un pensador cuya obra nos da herramientas para abordar el derrumbe actual de sentido y, sobre todo, cuyo concepto de abducción abre caminos para imaginar e instituir sentidos nuevos. Antes de adentrarnos en el concepto de abducción y sus usos específicos posibles en el presente contexto mundial en secciones subsecuentes, me interesa dedicar lo que resta de esta sección introductoria a situar y explicar los motivos y relevancia de mi aproximación interdisciplinaria a Peirce.

Al aproximarme a Peirce ciertamente no parto de la filosofía disciplinaria Ilustrada. Mi acercamiento al pensador estadounidense es desde un lugar profundamente interdisciplinario, informado tanto por la metodología de los conceptos viajeros de Mieke Bal (2002) y el campo del análisis cultural formalizado por la autora y en el cual estoy formada, como por la Teoría Crítica de la Escuela de 2- Véase Agencia EFE (Redacción), 2020; y Marco Lambertini, Elizabeth Maruma Mrema y María Neira, 2020. 
Frankfurt con la que comparto visión. Considero necesaria esta aclaración pues la reflexión sobre el trabajo de Peirce -sobre todo en lengua hispana- ha estado acotada en mayor o menor medida a la filosofía disciplinaria tradicional, es decir, a los métodos, criterios y fines de reflexión teórica en ciencias sociales y humanidades que prevalecían a partir de la Ilustración y hasta antes del giro lingüístico en el pensamiento Occidental. Ese giro condujo a articular pensamiento teórico legítimo en las ciencias sociales y humanidades desde una interdisciplinariedad profunda, como lo hicieran Michel Foucault, Jacques Lacan, Jacques Derrida y Roland Barthes.

Los métodos y criterios de la teoría tradicional, como aclarase Max Horkheimer en un texto incluso previo al giro lingüístico, están organizados alrededor de una concepción de la teoría como sistema cerrado de conocimiento, sin contradicciones internas, elementos superfluos, ni intereses mundanos (2003: pp. 223-25). ${ }^{3}$ Sin embargo, como argumenta el pensador alemán, la híper-especialización científica de la teoría tradicional es correcta pero ciega, ya que no contesta preguntas fundamentales respecto a su lugar y función en la sociedad, presentándose como puro medio y renegando de sus fines, del mismo modo que reniega de los intereses extra-científicos que dan lugar, espacio y recursos para su existencia y desarrollo específicos (p. 258). ${ }^{4}$ Como argumenta Horkheimer, mientras menos evidente sea el empleo instrumental de determinados quehaceres científicos (como en el caso de la filosofía pura en oposición, por ejemplo, al desarrollo de armas), más astutamente instrumental resulta dicho quehacer intelectual para la perpetuación del status quo. Esto se debe a que su función para la totalidad social e ideológica de la que forma parte es justamente la de aparentar ahistoricidad, neutralidad y desinterés, y, de tal modo, legitimar al sistema que lo produce como natural, neutro y desinteresado (pp. 230-32 y 238-39).

Como plantea el fundador de la Escuela de Frankfurt, la validez -o verdad- de la teoría critica opera y no opera a la vez como la tradicional (2003, pp. 249-50). Lo crítico de la teoría reside en su perspectiva global, no en su contenido fáctico ni en su medio de ingreso (p. 252). La teoría crítica puede operar en cualquier ámbito científico o teórico; lo que la caracteriza en cualquiera de las áreas en las que opere es que no pierde de vista el marco general de las cosas ni el lugar de su actividad dentro de éste. Siempre se pregunta por los fines y evita contribuir a la actividad ciega de la sociedad a la vez que se esmera por entender cómo todo esfuerzo científico o teórico está ineludiblemente mediado por la actividad humana (pp. 239-42). En suma, la teoría crítica a diferencia de la teoría tradicional tiene como fin transformar en lugar de reproducir el sistema del que forma parte, analizando los procesos intelectuales con potencial transformador en condiciones históricas dadas (pp. 246-7). Es en este sentido que el presente artículo busca recuperar el potencial transformador de Peirce para el presente.

También he referido a Horkheimer para deconstruir la falsa oposición entre discurso científico y discurso ideológico. En "Teoría tradicional y teoría crítica” (2003), el texto fundacional de la Escuela de Frankfurt que he venido citando y que fue originalmente publicado en 1937, el filósofo y sociólogo alemán demuestra cómo, una vez que abrimos el foco y evaluamos la actividad científica más allá de sus propios términos de consistencia interna, una vez que su proceder se coteja con el contexto que le da

3- Esto aplica tanto para el idealismo en la tradición alemana como para el empiricismo en la tradición inglesa, véase Horkheimer, 2003, pp. 224-26. Por otra parte, lo que argumenta Horkheimer es que no es que la razon instrumental que motiva la ciencia tradicional sea incorrecta, simplemente es funcional al sistema que separa, cosifica y discursivamente deshistoriza la teoria (Horkheimer, 2003, p. 228-9).

4- La teoría critica lucha por transformar la necesidad ciega por otra plena de sentido (Horkheimer, 2003, p. 259). 
origen y forma, y sobre el cual repercute, la actividad y discursos científicos se develan como profundamente ideológicos, atados a intereses externos y determinados por ellos. En Dialéctica de la Ilustración (2007), libro que Horkheimer escribió con Theodor W. Adorno, los autores plantean que el gran mito de la Ilustración es que el pensamiento mítico ha sido superado y que en consecuencia ahora el mundo es perfectamente cognoscible mediante la razón y el pensamiento científico. Los autores proponen que tanto los rituales mágicos en las sociedades tradicionales como los rituales y retórica de la Ilustración son resultado del miedo del ser humano ante el mundo y de una necesidad de controlarlo o sentir que lo pueden controlar. Bajo el sistema actual, los seres humanos creen que se liberarán del miedo cuando todo sea conocido. De tal modo, la Ilustracion surge para erradicar el mito y las creencias mágicas pero se vuelve ella misma mito totalizante..$^{5}$ La Ilustración es el miedo mítico radicalizado.

Dado todo lo expuesto, lo inusual no es que un discurso científico sea ideológico, lo inusual, incluso imposible, sería que no lo fuese. Así lo sugiere el propio Adorno en Dialéctica negativa, publicada originalmente en 1966, cuando plantea que todo acto epistemológico es inherentemente ideológico. Esto se debe a que hay una continuidad entre los procesos de identificación e identidad que habilitan nuestro acto de pensar y la ideología como tal. Los conceptos nacen de la modalidad identitaria del pensamiento y operan como una ideología en diminuto al hacer violencia a la realidad que dicen representar. Un concepto es por definición una reducción de la realidad y esta última siempre será más compleja que el aspecto que un concepto abstrae de la misma. Por lo tanto, el concepto no le hace justicia, no es representación neutra u objetiva, ilumina una parte de lo representado a la vez que ensombrece otra. Como he explicado anteriormente:

Para Adorno, la síntesis es una etapa necesaria en el proceso del pensamiento, la abstracción es esencialmente sintética, y los conceptos son estabilizaciones provisionales de tales síntesis. Por ende, la identificación es constitutiva de cualquier esfuerzo epistémico. Al mismo tiempo, Adorno muestra que el acto de síntesis, esa voluntad de identidad a la que el pensamiento se entrega, abusa de la realidad que pretende explicar, ya que es inevitablemente un acto de exclusión (1983, pp. 146-48). Por lo tanto, una crítica de la ideología es siempre ya una crítica de nuestro modo de conocer. Para avanzar, dicha crítica debe emplear las herramientas que se propone criticar. Teniendo en cuenta que todo concepto y toda ideología es una violación, en el sentido de que excluye y al mismo tiempo niega su propio acto de exclusión, su crítica debe negar esa misma negación. Esta negación de la negación se produce al realizar dentro del concepto o de la ideología lo que el concepto o la ideología promete y sin embargo deniega. (Adorno, 1983, p. 147) (Aroch Fugellie, 2015, p. 67) ${ }^{6}$

5- A la magia, como a la ciencia, le interesan los fines, no la relación entre fines y medios. El pensamiento mágico antiguo, a diferencia del Ilustrado, no niega su afán de dominación. El pensamiento mágico pre-Ilustrado construye su mito mediante la mimesis y lo antropomórfico, mientras la Ilustración lo hace mediante una creciente distancia del objeto. Ambos dominan pero uno con prácticas locales, otro con la totalidad de la tecnología industrial. La Ilustración disuelve la dominación directa pero la universaliza y desplaza a la falsa conciencia de la totalidad (Adorno y Horkheimer, 2007).

6- Además: “Como Adorno argumenta con respecto al principio de trueque, la totalidad 'debe ser afrontada condenándola a la no-identidad consigo misma, a la no-identidad que niega, según su propio concepto' (1983, p. 147). Esta crítica de la totalidad, del capitalismo, de la ideología en general, debe operar en y por medio de, así como en contra de, el modo identitario del pensar, porque es inmanente al pensamiento. Por lo tanto, Adorno afirma que la crítica de la ideología "es una crítica de la propia conciencia constitutiva' (p. 148)." Véase Aroch Fugellie p. 74 
De tal modo, no se puede articular un discurso científico -ni de cualquier otra índole- más allá de nuestra propia intermediación subjetiva (ni independientemente de los medios y herramientas de conocimiento empleados). Esta concepcion resulta fundamental para entender la operacion del mapa como representacion declaradamente "cientifica", "objetiva" y "neutra" que examino más adelante, en la seccion tres.

Los pensadores de la Escuela de Frankfurt historizaron así las ciencias, la razón ilustrada, el pensamiento científico y el pensamiento como tal. Pero fue hasta después del giro lingüístico en el pensamiento Occidental, y sobre todo hasta después del giro poscolonial desde Asia y África y decolonial desde América Latina, que queda más ampliamente aceptado en las ciencias sociales y humanidades que el conocimiento es situado, que el lugar desde el que se habla es determinante en la conformación de aquello que se dice, que toda teoría es histórica y que su alcance "universal" es siempre provisional tanto en términos históricos como geo-políticos. Hay un sinnúmero de autores que han dejado este legado pero, por mencionar sólo algunos de diversos orígenes y escuelas, podemos pensar en Néstor García Canclini, Gayatri Spivak, Walter Mignolo, Valentin-Yves Mudimbe y Aníbal Quijano. Es más, incluso en las ciencias naturales (que como bien indica Horkheimer, las ciencias sociales toman como modelo [2003, p. 225]), ha quedado ya desde hace tiempo claramente establecido que no hay verdades absolutas que trasciendan su marco de referencia, y que no hay marco de referencia privilegiado. Así, por ejemplo, la mecánica newtoniana no es incorrecta, pero sólo es cierta en un contexto delimitado. El propio Albert Einstein, como he indicado en otra parte, sostiene que el espacio como tal:

No es simplemente un recipiente vacío y divisible, sino un campo interactivo: "El espacio y el tiempo son ahora cantidades dinámicas: cuando un cuerpo se mueve, o una fuerza actúa, afecta la curvatura del espacio y del tiempo" (1920, p. 153). Como explica Einstein: "De acuerdo a la teoría general de la relatividad, las propiedades geométricas del espacio no son independientes, sino que están determinadas por la materia” (1920, p. 151). Al desestabilizar las nociones clásicas de esas dimensiones, Einstein introdujo la cuestión de los marcos de referencia. Los marcos de referencia inerciales (relativos a la resistencia de los cuerpos al cambio en su estado de reposo o movimiento) estaban aceptados por la mecánica clásica. La innovación de Einstein en 1905 fue postular que no hay un marco privilegiado, que no hay un tiempo verdadero e independiente que se distorsione sólo desde ciertas perspectivas. (Aroch Fugellie, 2010. p. 64)

Más aún, hoy en día la objetividad en las ciencias duras, como elabora el físico uruguayo Rodolfo Gambini, se define en términos relacionales: la objetividad no reside en la independencia de enunciados dados a cualquier referencia de participación humana, sino a su independencia de un observador particular (1999, p. 27). Gambini aclara que la noción Cartesiana de la realidad como aquello cognoscible matemáticamente ya no es vigente hoy en día. Esto no quiere decir que la realidad no sea susceptible de análisis riguroso, sino que dicho análisis no rinde cuenta de toda la realidad y sólo refiere a ella de manera indirecta, mediante la descripción exacta de nuestras operaciones sobre la realidad y respuestas expresadas a través de conceptos operacionalmente definidos y cuantificables (Gambini, 1999, p. 46; véase también Aroch, 2010, p. 61).

7- Esta y todas las demás traducciones de publicaciones en inglés son mías. 
Tanto desde la física, como desde la teoría crítica clásica (Escuela de Frankfurt) y las teorías críticas contemporáneas (poscolonialismo, posestructuralismo y escuela decolonial) prevalece la idea de que los cuerpos -ya sean físicos o de conocimiento- son susceptibles a su entorno, se modifican y encuentran validez distinta de acuerdo a su interactividad con el espacio y tiempo donde operan. Por ello, quiero investigar cómo Peirce opera más allá de su lugar y tiempo de enunciación original, para explorar su potencial hoy en día, en el contexto de la crisis planetaria que derrumba, entre otras cosas, la estabilidad de nuestros horizontes acostumbrados de sentido. Me interesa también averiguar cómo co-construimos a Peirce en su recepción, con el fin de rescatar su capacidad de transformación, reivindicar su teoría a partir de una nueva finalidad. En otras palabras, esta es una apropiación de Peirce como teoría crítica desde el Sur contemporáneo.

En la siguiente sección, justifico la importancia de la recuperación de Peirce desde el Sur contemporáneo y elaboro mi lectura del COVID-19 como síntoma de un capitalismo colonial basado en el principio de sobreexplotación tanto de otros sujetos como de los recursos materiales del globo terrestre. El punto central, para los fines de este artículo, es que esa crisis objetiva del sistema implica también una crisis de legitimación del mismo: los significados y sentidos que se alineaban para su operación han dejado de ser funcionales. Es en el contexto de dicha crisis de sentido que se hace necesario recurrir a un modo de pensamiento que permita la emergencia de lo nuevo. El concepto peirciano de la abducción es, por excelencia, el tipo de lógica que abre paso a la ocurrencia de lo inimaginado en el campo del concepto.

Pero, además, en la lógica peirciana, el ámbito de lo conceptual está profundamente entrelazado con el ámbito material. Así, por ejemplo, un signo es una cosa que representa otra, no es sólo la mera función representacional abstracta; el signo siempre participa de una dimensión en el mundo de lo cualitativo (véase Peirce, CP 2.228). Por tanto, la reconstitución conceptual del mundo que permite la abducción conduce necesariamente a una renovación en el ámbito de lo material. Y, desde la postura materialista dialéctica desde la que escribo (pensemos, por ejemplo, en Stuart Hall [1997] o clásicamente en Antonio Gramsci) - se puede agregar que no es el concepto el que inaugura la transformación material, ni viceversa, sino que existe una determinación recíproca entre ambas esferas.

También pensando desde el materialismo dialéctico, es importante aclarar que a lo largo de este artículo no quisiera sugerir que la recuperación del concepto de abducción es lo que va a llevar a la emergencia de nuevos paradigmas que estructuren salidas inéditas a la crisis de sentido que vivimos en la actualidad - y la cual se agudizó con la pandemia. Tales emergencias son resultado de procesos históricos. Lo que sí nos permite el recuperar el concepto de abducción, reflexionarlo y actualizarlo en su cotejo con el presente, es tener mayor dominio sobre este hueco de lo viejo que se quebranta y sobre el impulso de lo nuevo que brota a la superficie, mayor espacio de acción y decisión sobre el mismo. En otras palabras, dado que ya estamos en un momento de cambios paradigmáticos, dado que ya estamos en un momento propenso al pensamiento abductivo, se hace pertinente profundizar en el concepto que nombra dicha lógica.

Nietzsche escribió respecto a las contradicciones y los afectos propios, que podemos "montarnos sobre ellos como sobre caballos" no para resolverlas ni diluirlos sino para mantenernos al mando; lo mismo con las crisis, cambios, ajustes y desajustes de sentido del presente: no se trata de desaparecerlos, sino de domarlos, andarlos y guiarlos con mucha mayor deliberación (Nietzsche, 2002, p. 171). 
Recuperar, analizar y actualizar en este momento histórico el concepto de abducción nos permite cabalgar con mayor conciencia esas fuerzas que irrumpen tras el derrumbe de algunas de las estabilizaciones de sentido que operan de manera transparente en el contexto del capitalismo colonial y que hoy comienzan a resquebrajarse como resultado de la crisis de sobreexplotación propia del sistema y su expresión en la pandemia.

\section{Mapas nocturnos para habitar un mundo post-covid}

Al volver la mirada hacia Peirce desde el Siglo XXI y desde el Sur planetario resulta fundamental no perder conciencia de nuestro propio lugar y tiempo de interlocución. El COVID-19 ha traído consigo una crisis de representación que, a diferencia de aquella que desencadenó la Segunda Guerra Mundial y a la que la Escuela de Frankfurt fue una respuesta, demanda respuestas desde el Sur Global. Es por ello que aquí secundo el llamado de Dussel a la defensa de la vida como urgencia ética ante la cosificación irresponsable de la misma, propia de la modernidad capitalista colonial que desencadenó la pandemia. Por ello también, busco trazar lo que Jesús Martín Barbero llamase un "mapa nocturno" que registre la actual crisis de sentido y permita reimaginar -y quizás rehacer- el mundo desde otro lugar.

Hace ya más de 30 años, Martín Barbero re-mapeó el campo de los estudios de la comunicación en al menos dos sentidos. Primero, en el sentido de reubicar sus contenidos, dinámicas, estrategias y procederes internos (por ejemplo, al trazar las continuidades entre medios y mediaciones sociales; y entre audiencias y el potencial transformador apropiable de la massmediación). Segundo, en el sentido de desplazar las articulaciones geo-políticas del campo de la comunicación, revelando de forma inédita la determinación recíproca entre la experiencia latinoamericana y la conformación del campo. Así, los dos re-mapeos que he indicado resultan no ser independientes: la transformación que su libro De los medios a las mediaciones. Comunicación, cultura y hegemonía ([1987] 1998) implicó en cuanto al enfoque temático y métodos del campo de la comunicación, es indisociable del desplazamiento geográfico de su pensar, de su desde dónde elaborar la experiencia para convertirla en reflexión teórica.

Ese gesto geopolítico rompe con ciertas presuposiciones fundacionales que habían prevalecido en el terreno de la comunicación. Me refiero a presuposiciones tales como que Europa y América al norte del Río Bravo son el lugar natural para la teoría. Si bien tales presuposiciones no permanecían incuestionadas en 1987 -recordemos que la escuela latinoamericana de la comunicación surge ya desde los años 1960- sí subsistía su hegemonía, es decir, perduraba la naturalización de la metrópolis global como el lugar privilegiado para la emergencia de la teoría comunicativa y su regulación (véase Shome y Hegde, 2002). Esos presupuestos dados son los que De los medios a las mediaciones llega a desestabilizar de manera profunda con su sistemática develación de los vínculos entre la teoría comunicativa (pseudo-universal) y su radical contingencia, su historicidad, su enredamiento con intereses económicos, sociales, culturales, ideológicos y geopolíticos.

Las presuposiciones fundacionales de un campo son aquello que sostiene, codifica y sistematiza sus operaciones. A la vez, son punto de fuga, el sitio de acceso al origen mundano de una teoría, marcan su lugar de interés, son indicador de su operación extra-teórica. Son el índice ideológico por excelencia

que, como tal, solo puede sostener, funcionalizar y habilitar la operación de un campo siendo punto ciego, naturalizado y olvidado. Treinta y tres años después de la reconfiguración del campo iniciada 
por Martín Barbero y ante la desubicación generalizada de nuestros mapas teóricos y existenciales a causa del COVID-19, es momento para volver a los cimientos de los campos dedicados al análisis de nuestros procesos comunicativos y de producción de sentido.

Explorar la intersección entre distintos campos pertinentes al estudio de procesos de significación social, incluyendo la comunicación y la semiótica es relevante hoy más que nunca. En algunos ámbitos de los estudios sociales y culturales contemporáneos circulan prejuicios en torno a la semiótica como campo cerrado de producción de significado. ${ }^{8}$ Sin desconocer los límites que el campo -como cualquier otro- tiene, quisiera centrarme en lo que estos límites posibilitan y los mundos que abren, bajo el entendimiento de que el afán estructuralista de la semiótica no necesariamente se traduce en una aproximación ahistórica. Me interesa volver, desde otro lugar, al trabajo de Charles Sanders Peirce (1839-1914), padre de la semiótica pragmática y pensador profundamente interdisciplinario; quisiera volver en específico a su concepto de la abducción. ${ }^{9}$

Al igual que la deducción y la inducción, la abducción es un método de razonamiento. Pero, a diferencia de esos otros métodos, la abducción es una lógica inconsciente, no racional; en otras palabras, no es constituyente sino instituyente de la razón y la consciencia. La abducción se asocia a procesos artísticos y también permite la emergencia de nuevos paradigmas científicos. La abducción es contradicción constitutiva de la semiótica como campo, siendo a la vez concepto teórico e índice de lo que reside más allá de la teoría. ${ }^{10} \mathrm{Al}$ igual que K. T. Fann (1970), sostengo que la abducción es la lógica del descubrimiento y el aspecto esencial del pragmatismo de Peirce. En este sentido, tal como he argumentado anteriormente, la abducción es a la vez parte del cuerpo teorico de Peirce e índice de lo que reside más allá de la teoría, elemento constituído y momomento instituyente de la misma.

Ya que es una de las presuposiciones fundacionales del campo, el enfoque en la abducción permite un análisis del punto de encuentro entre la semiótica como campo teórico y sus articulaciones más allá de sí. Finalmente, quiero señalar que al ser método de razonamiento que abre paso a una radical re-imaginación, re-teorización y re-habitación del mundo, la abducción se vuelve demanda urgente tras la pandemia del COVID-19. El virus ha jaqueado no sólo nuestro DNA como campo de información, ${ }^{11}$ no sólo algunos de nuestros cuerpos individuales y colectivos, sino también nuestro mapamundi geopolítico, socio-racial, ideológico y semiótico; ha desestabilizado nuestro lugar en el mundo, entendido éste como una serie de coordenadas y entramados a nivel biológico, ecológico, histórico, cultural, psicológico y ontológico.

Enrique Dussel ha empleado la metáfora del jaqueo para describir cómo el virus aparece como índice incuestionable de que la modernidad capitalista colonial se ha erguido sobre la cosificación irresponsable de la vida y la naturaleza. Dussel llama a:

\footnotetext{
8- Esto ha dado pie a la emergencia de la sociosemiótica, véase por ejemplo Horta, Paulín y Flores, 2019.

9- Como elabora Robert Burch en la Stanford Encyclopedia of Philosophy: "Charles Sanders Peirce ... fue el fundador del pragmatismo estadounidense ... teórico de la lógica, del lenguaje, de la comunicación y de la teoría general de los signos ... prolífico lógico-matemático y matemático general, y desarrollador de un sistema metafísico ... . Aun siendo un químico practicante y geodesta de profesión, consideraba a la filosofía científica y, en especial, a la lógica, como su vocación” (2021).

10- Para un estudio a detalle de la abducción y su lugar en la teoría de Peirce, véase Fann, 1970.
}

11- El virus es un RNA, que, como ácido nucléico esencial para la codificación, decodificación, regulación y expresión de genes es muy cercano al DNA. El virus sustituye el DNA consigo mismo y usa la célula anfitriona para replicarse. 
Interpretar la presente epidemia como si fuera un bumerán que la modernidad lanzó contra la naturaleza (ya que es el efecto no intencional de mutaciones de gérmenes patógenos que la misma ciencia médica e industrial farmacológica ha originado), y que regresa contra ella en la forma de un virus de los laboratorios o de la tecnología terapéutica. (2020a, p. 89)

Pero incluso más allá de leer la pandemia como síntoma de la parte obscura -parte formativa pero negada- de la modernidad capitalista colonial, la retórica y metáforas que emplea Dussel enfatizan la mismísima legibilidad del evento. En otras palabras, el autor resalta cómo la pandemia irrumpe de manera radical en nuestras lecturas pre-establecidas del mundo, lecturas que, por otra parte, son constitutivas del mismo. Así, por ejemplo, a lo largo del ensayo se centra en la problemática hermenéutica que representa la pandemia, refiere reiteradamente a la misma como "signo" (2020, p. 88-90) y cierra poniendo énfasis en el descoloque interpretativo y necesidad de nuevas imaginaciones del mundo que surgen a partir de la pandemia: "En el silencio de nuestro retiro exigido por los gobiernos para no contagiarnos de ese signo apocalíptico... tomemos un tiempo en pensar sobre el destino de la humanidad en el futuro" (2020, p. 90).

Ante una pandemia entendida como signo posible del fin de la modernidad capitalista colonial, ante un mundo concebido no sólo como fenómeno objetivo, sino como comunicación jaqueable, adquiere particular importancia la reflexión articulada en los entrecruces de distintos campos que nos ayudan a entender procesos de significación social, como lo pueden ser los estudios de la comunicación y la semiótica. Estos campos abren paso al mapeo de nuestro lugar en el mundo en sentido literal y metafórico, y al mapeo de ese mundo como aquello que acontece en la dialéctica entre subjetividades y sus mediaciones objetivas, entre objetos y sus mediaciones subjetivas, entre signos entendidos como función y signos entendidos como soporte material de las mismas, entre información físico-biológica o matérico-tecnológica e información psico-ideológica y socio-política, entre condiciones objetivas de posibilidad y desigualdades estructurales constitutivas, entre historia de lo pasado e imaginación radical de lo posible.

Es con esa perspectiva en el horizonte que en la tercera y cuarta sección exploraré cómo una proyección cartográfica de Peirce y su concepto de abducción sirven como piedras fundacionales para la construcción de representaciones geográficas, geopolíticas y teóricas de los mundos que habitamos y cómo estos procesos de producción, institución y/o deconstrucción de significado iniciados o captados por Peirce pueden servirnos para reimaginar el planeta que seguimos construyendo (o destruyendo) hoy en día. Desde la semiótica pragmática de Peirce, parto de la presuposición de que nuestros procesos de producción de significado no sólo representan, sino que hacen mundo. ${ }^{12}$ En la siguiente sección exploraré su proyección quincuncial del globo terrestre, para luego centrarme en su concepto de abducción en la sección subsecuente. En ambos casos, articularé la relación entre el trabajo de Peirce y sus usos posibles para nuestro repensar el mundo (y el lugar desde el cual articulamos ese pensamiento) en la perspectiva de la actualidad. Este recorrido es algo así como un "mapa nocturno", una cartografía a tientas de configuraciones posibles del mundo, entendido éste como construcción semiótica atravesada por la infalible historicidad del presente. Escribir sobre los entrecruces entre distintos campos para el estudio de procesos de significación social en el contexto de una pandemia 
mundial demanda no sólo una revisión de los mapas conceptuales y geopolíticos que recorremos como habitantes y estudiosos del planeta, sino también de las propias herramientas de trazado, al tiempo que seguimos avanzando en la semioscuridad.

Jesús Martín Barbero fue quien consagró la metáfora del mapa nocturno para referir a un campo en transformación continua. El reposicionamiento geográfico autorreflexivo que lleva a cabo Martín Barbero le conduce a repensar la propia teoría de la comunicación como fenómeno histórico, receptivo a las transformaciones sociales y geopolíticas que le circundan y, particularmente, a las prácticas comunicativas como aquello sin lo cual la teoría quedaría desvinculada del sentido y la sustancia que la motivan. Es este profundo entendimiento de la teoría misma como práctica comunicativa lo que funcionaliza la metáfora del mapa nocturno. En palabras del autor:

Desplazados los linderos que demarcaban las instancias, es el mapa de los "conceptos básicos", de que habla [Raymond] Williams, el que necesitamos rehacer. Pero no creo que ello sea posible sin cambiar de lugar, sin cambiar el lugar desde el que se formulan las preguntas. Es lo que expresa en los últimos años la tendencia a colocar preguntas que rebasan la "lógica diurna" y la desterritorialización que implica el asumir los márgenes no como tema sino como enzima. (1998, p. 292)

La invocatoria de Martín Barbero sigue vigente 33 años después. Esto se debe a que el mapa nocturno "no es solamente una frase poética afortunada sino un enunciado filosófico (Diógenes, los cínicos) sobre un campo de investigación en permanente construcción" (Gumucio, 2017, p. 127). Además de referir a la búsqueda que caracteriza al campo, y de hacerse particularmente relevante ante la fuerza desestructurante del virus que reconfigura nuestro presente, la metáfora de un mapa nocturno permite desplazarnos entre disciplinas: de la comunicación a la geografía y a la semiótica para explorar en qué medida el trabajo de C.S. Peirce puede ser herramienta y compás en nuestro viaje por un presente que demanda nuevas teorizaciones para prácticas atestiguadas desde situaciones inéditas de enunciación.

El planteamiento de Martín Barbero de que el sitio desde el cual se articulan las preguntas afecta las respuestas resuena con la preocupación central de C. S. Peirce por cómo la relacionalidad entre elementos determina dichos elementos, tanto en el campo de la representación geográfica como en el de la teorización semiótica. En la siguiente sección exploraré las distancias y continuidades entre los mapeos que trazó Peirce como investigador en semiótica y como geodesta y entre algunos mapas literales y conceptuales producidos desde su época hasta la nuestra. Incluiré distintos mapas del globo terrestre y mapeos teóricos de la pandemia sin perder de vista los efectos de sus contextos de recepción, desde la escuela hasta el Internet. Todo esto para apuntar algunas posibilidades que puede ofrecernos Peirce en tiempos de cambio profundo y reflexión necesaria de nuestro lugar en el mundo natural, tiempos también de transformaciones significativas en nuestras teorías y tecnologías de comunicación. Con esto, hago una llamada desde el Sur del orbe y del pensamiento a ver en Peirce a un intelectual que luchó contra la hegemonía teórica en los campos de la semiótica, de la geodesia y de la lógica. Un elemento clave en el ímpetu contra-hegemónico de Peirce -además de su énfasis en la relacionalidad como constitutiva de los términos relacionados- reside en su incorporación del vértice de lo ilógico, lo inconsciente y lo intuitivo en el estudio de la lógica. Esto último se verá en la cuarta sección. Por lo pronto atendamos el mapamundi clásico de Peirce, su proyección quincuncial del mundo. 


\section{3. $\mathcal{E}$ l mundo según Peirce}

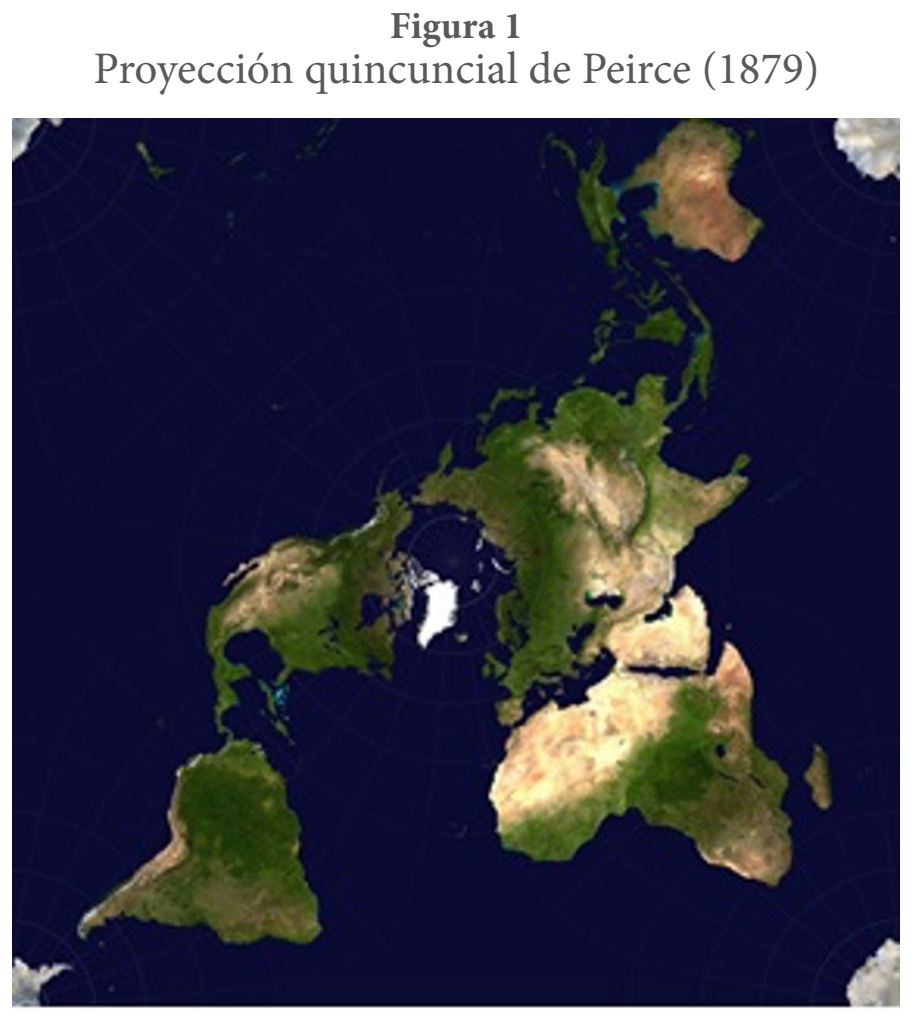

Wikimedia Commons, Creative Commons, 2006.

La imagen de la Figura 1 es una cartografía del mundo según Charles Sanders Peirce. Mejor conocida como su proyección quincuncial, Peirce la desarrolló en 1879 , con la particularidad de ser una proyección "conforme". En el ámbito de la geometría, "conforme" significa que está basada en una función matemática que preserva en la representación cuadrangular y bi-dimensional del globo terrestre los ángulos originales, tal y como se presentan en la superficie esférica de la tierra (con la excepción de las cuatro esquinas del cuadrado o rectángulo, dónde tal "conformidad" falla).

Aunque la proyección quincuncial tuvo poca difusión y utilidad práctica en su momento (con excepción de su uso por parte de la Fuerza Aérea Estadounidense para el trazo de rutas aéreas durante algún tiempo), en 1967, casi cien años después de que la diseñara Peirce, el cartógrafo alemán Arno Peters la tomó como referencia central en su propia proyección cartográfica. La proyección de Peters fue revolucionaria al dejar en evidencia cómo la cartografía establecida desde el siglo XVI era más un reflejo de la historia del imperialismo mundial que de los tamaños reales de los distintos continentes.

En la época de Peters y hasta hoy en día, la imagen del mundo más legitimada, la cual desde hace casi quinientos años se ha enseñado como la representación científica de la realidad geográfica de nuestro planeta, es la proyección que hiciera en 1569 el cartógrafo flamenco Gerardus Mercator. La proyección de Mercator es la de la Figura 2: 


\section{Figura 2}

\section{Proyección de Mercator (1569)}

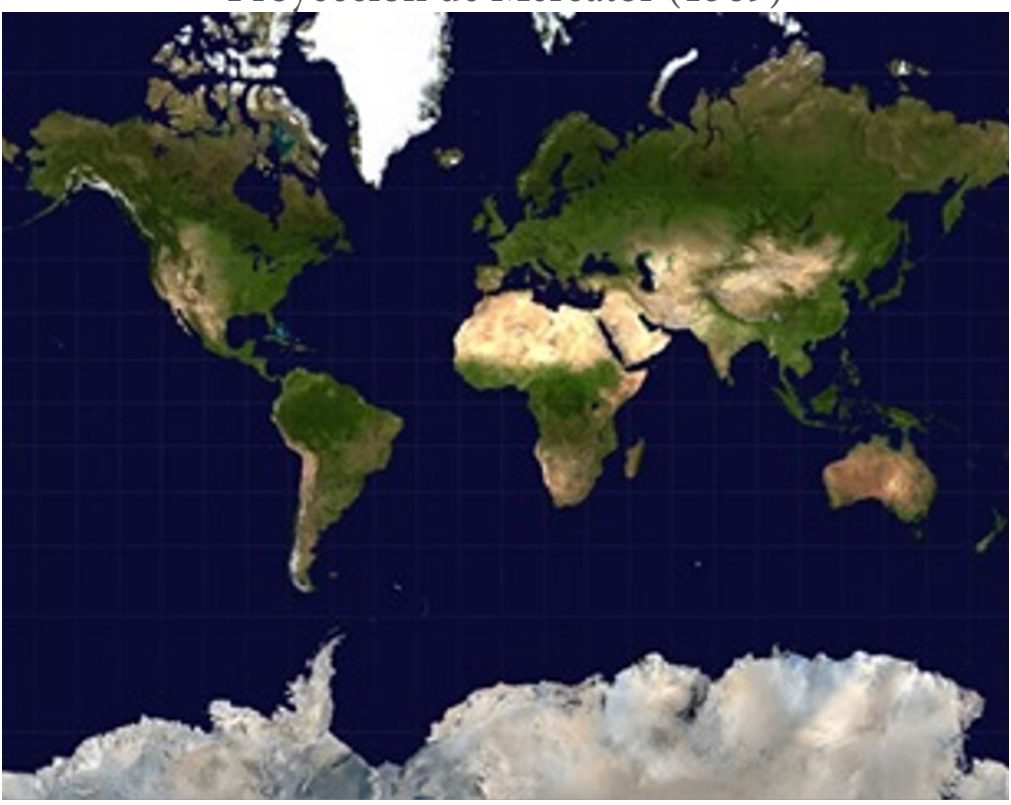

Wikimedia Commons, Creative Commons, 2008.

Cabe recordar que representar una esfera sobre una superficie plana necesariamente altera las proporciones de las masas terrestres representadas en alguna parte del plano. Pero precisamente cuáles áreas se hacen más grandes y cuáles más chicas es una elección ideológicamente informada. Nótese cómo los espacios entre las líneas de latitud, que en una esfera serían equidistantes, se hacen más amplios sólo hacia la parte de los continentes del norte en la Figura 2 (y nótese cómo esto no sucede en el mapa de Peirce, Figura 1). La naturaleza totalmente arbitraria de las proporciones asignadas a Europa y Norteamérica, por un lado, y a Sudamérica y África, por el otro, puede apreciarse mejor al compararse un mapamundi basado en la proyección más común (la de Mercator, Figura 2), con la proyección que Peters desarrollara a partir de Peirce (Figura 3):

\section{Figura 3}

Proyección de Peters (1967)

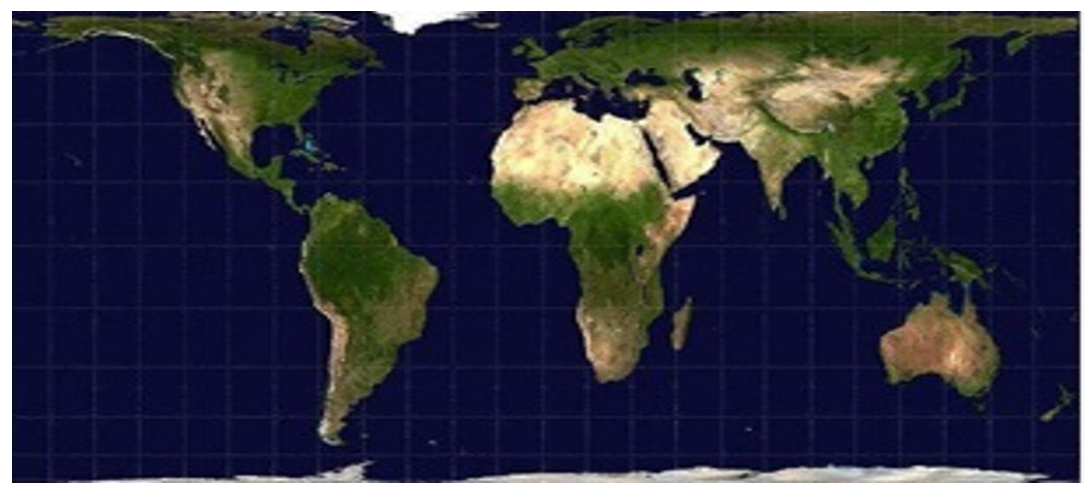

Wikimedia Commons, Creative Commons, 2009. 
Nótese cómo, en el mapa de la proyección de Mercator (Figura 2), Norteamérica se ve del mismo tamaño que África, o incluso un poco más grande. En realidad, es decir, en términos de superficie en metros cuadrados, África es tres veces y medio más grande que Norteamérica. En el mapa de Mercator, Groenlandia se ve casi del tamaño del continente africano. Sin embargo, en kilómetros cuadrados, África mide 30 millones de kilómetros, mientras que Groenlandia mide sólo 2 millones. La proyección de Peters es más precisa en tanto que es una representación visual mucho más fiel a las medidas físicas de los continentes. Como indica el antropólogo de la Universidad de Stanford, James Ferguson, "si uno pone un mapa de Europa dentro de la República Democrática del Congo, con Londres en la costa occidental, Moscú quedaría dentro de la frontera al oriente" (2006, p. 27). Sin embargo, nuestra concepción del tamaño relativo de Europa o EEUU en comparación con África sigue estando deformada de acuerdo con la imaginación eurocéntrica. Esto se debe a que el mapa de Mercator ha sido enseñado a millones de niñas y niños en escuelas en toda la tierra durante quinientos años y, como indicara Jonathan Culler, la ideología no es más que la naturalización de una narrativa (1973, p. 471); definición que se alinea con la concepción adorneana de la ideología expuesta anteriormente.

A través de Peters, el trabajo de Peirce como cartógrafo contribuyó a exponer el gran peso de la visión eurocéntrica del mundo en la construcción del mismo a través de un discurso legitimado por su carácter "científico". Esos quinientos años en los que prevaleció -y en gran medida aún sigue prevaleciendo- la proyección de Mercator como representación hegemónica de nuestro orbe corresponden, a grosso modo, al periodo que Dussel refiere como modernidad capitalista colonial, el cual, según sostiene el filósofo argentino, el COVID-19 llega a poner en jaque (2020b). La proyección de Peirce, como forma específica de representar el mundo con una imagen, así como su desarrollo histórico posterior con Arno Peters, son un antecedente útil para la reimaginación del mundo que demanda la pandemia global contemporánea y sus futuros inciertos.

Además, aquí se pone de relieve la cuestión de la representación como forma de mediación, como medio que comunica imaginaciones y, eventualmente, realidades posibles de un mundo en construcción. De tal modo, la breve historia cartográfica que he recorrido en esta sección pone en evidencia un punto central para Peirce: muestra que cómo observamos y desde dónde observamos, por un lado, y aquella realidad que observamos, por el otro, no son cosas independientes. El estudio de la relación constitutiva entre representación y realidad es un interés fundamental del campo de la semiótica pragmática que fundara Peirce, más allá de su práctica como geodesta.

El quehacer cotidiano de Peirce como cartógrafo en la USA National Geodetic Survey se articula por vías inéditas con su exploración formal de la semiosis. Entre su práctica cartográfica y su teoría semiótica opera una lógica abductiva, la pujanza de una ruta no establecida. La proyección quincuncial muestra de manera literal cómo el mundo está co-constituido por nuestra figuración del mismo, y denota la importancia de la relacionalidad en el pensamiento de Peirce. El interés central en la proyección en cuestión era preservar los ángulos entre los continentes. Peirce estaba interesado en realizar una proyección que privilegiara la relación entre masas terrestres por encima de esas entidades en sí mismas y por encima de su disposición espacial estabilizada a partir de una jerarquía entre nociones como "Norte" y "Sur", naturalizadas pero arbitrarias.

Desde Peirce a la fecha, ha habido un sinnúmero de deconstrucciones de la representación hegemónica del globo terráqueo fuera del ámbito de la representación científica en la que se inscriben Mercator, Peirce y Peters. Por nombrar sólo un par de ejemplos elaborados desde Latinoamérica y África, 
podemos pensar en el mapa invertido del artista uruguayo Joaquín Torres-García (donde aparece el polo sur en la parte superior del plano) o en la deconstrucción narrativa que hace el pensador keniano Ali A. Mazrui cuando explica cómo nuestra concepción del "Norte" y del "Sur" del mundo no tiene ningún sustento científico, ya que tal realidad implicaría a un observador externo "parado" en el espacio sideral observando la tierra y detectando "objetivamente" un "arriba" y un "abajo" de la misma. Agrega Mazrui que la única base para la asignación de "Norte" y "Sur" es la historia de poder que permitió a los continentes del norte legitimarse, literalmente, como la cima del mundo (1986, p. 23-33).

Pero quizás las deconstrucciones más masivas del mapamundi de Mercator han venido a partir de las nuevas tecnologías de información y comunicación, del Internet en particular, donde podemos encontrar dicha proyección intervenida y adaptada de diversas formas -los múltiples mapas del COVID-19 que circulan en el ciberespacio hoy son un buen ejemplo- en las que la proyección hegemónica del globo siempre está a un clic de proyecciones cartográficas alternas. Nuestra navegación por el Internet, más allá de los mapas literales que pueda ofrecer como contenidos particulares, también opera como un mapeo del terreno global, ubicándonos en un espacio altamente fragmentado y aparentemente heterogéneo, aunque con la indudable gravitación a ciertos centros de hegemonía geo-lingüística, correlativos a intereses económicos e ideológicos.

Es este el contexto en el que llega la pandemia trayendo consigo una crisis de representación, como sugerí anteriormente en referencia a Dussel. Esta crisis tiene antecedente en aquella que, tras el Holocausto, la Segunda Guerra Mundial y la amenaza de la extinción de la humanidad mediante la bomba atómica, llevó a la pérdida de la fe Ilustrada en la ciencia, la tecnología y el progreso, produciendo, entre otras, la crítica de Escuela de Frankfurt, y develando los discursos científicos como meras narrativas, tal y como se refirió en la introducción. La crisis de representación desencadenada en la posguerra como la precipitada por el COVID-19 tienen en común un desencanto con las lecturas preestablecidas del mundo, un sentido de su insuficiencia, proveniente de una amenaza existencial a la humanidad, amenaza radicalmente ligada al cuerpo y a nuestra fragilidad. Ante esta amenaza al cuerpo biológico, individual y colectivo, se yergue la palabra para reinventar esos cuerpos desde los imaginarios compartidos que, como postula la semiótica pragmática de Peirce, los co-constituyen, para encontrar una nueva relacionalidad entre los cuerpos y su hábitat, nuevas maneras de persistir en el planeta. ${ }^{13}$

No es casual la proliferación de interpretaciones de filósofos consagrados a partir de la pandemia, varias de las cuales aparecen compiladas en el ampliamente difundido volumen de Sopa de Wuhan (2020). ${ }^{14}$ Pero, aunque autores célebres ofrezcan verdades que nos pueden dar seguridad en tiempos inciertos, a veces la propia lógica del mercado académico conduce a que aquellos discursos que han sido ampliamente aceptados y valorados se reproduzcan una y otra vez de manera dogmática, en una especie de aferramiento a certezas consabidas, funcionando más como aliciente para tiempos de incertidumbre ontológica y política, resistiendo el quebranto inevitable de lo viejo y la emergencia de visiones nuevas, la irrupción de lo insospechado. Es pertinente aquí la premisa que sostiene, entre otros, Martín Barbero, al proponer que el desplazamiento del sitio de enunciación

13- La relación entre cuerpo y palabra en tiempos de crisis tiene otra vuelta de tuerca hoy en día: podría decirse, desde la biosemiótica, que el cuerpo, al estar amenazado por un virus, está amenazado por la posibilidad de reescritura de nuestra información genética.

14- Cabe anotar que Sopa de Wuhan fue fuertemente criticada por su mapeo racista del COVID-19, al asociarlo con China tanto en su título como en la ilustración de portada. 
trae consigo contenido novedoso para un campo. En Capitalismo y pandemia (2020), por ejemplo, vemos una compilación moderadamente más diversa intercalando pensadores consagrados de la metrópolis con lecturas vinculadas al "real" socio-político del Sur Global por parte de autoras menos conocidas que aportan resonancias distintas. ${ }^{15}$ En otro ejemplo, la comunicóloga mexicana Haydée García Bravo reconoce que la situación que estamos viviendo es inédita y nos deja sin palabra (2020). Por ello busca caminos a tientas, luces nuevas -que no respuestas infalibles- tanto desde la historia de la teoría científica como desde el cine contemporáneo. Este reconocimiento es justamente el punto cero para la explosión del razonamiento de tipo abductivo y la emergencia de un nuevo paradigma.

Quiero explorar a lo largo de la siguiente sección la posibilidad de entender la abducción como la emergencia de una conexión lógica antes inexistente, en contraste con la lógica entendida como una serie de interrelaciones ya emergidas. Recordemos que lo nuevo también es siempre ya histórico. Surge a partir de la emergencia de una latencia o potencial. Este potencial se puede detonar, activar o develar a partir de un desplazamiento del punto de vista o de enunciación. Me centro en la abducción en cuanto cimiento fundacional de la semiótica, gracias a la cual podemos entender la semiótica de Peirce como un campo que excede el estructuralismo que le da forma. Entendida así, la semiótica nos permite abordar no sólo la co-construcción de los ámbitos material e ideático del mundo, sino también su dimensión ideológica. La semiótica pragmática no invoca la producción y comunicación de significados como estructura cerrada, sino como evento radicalmente histórico. Por ello, se hace herramienta importante para abordar una pandemia que llega a arrasar no sólo con nuestras vidas a nivel biológico, sino también con nuestras formas establecidas de ser, hacer y comunicar (en) el mundo, con el imaginario colectivo que posibilitaba esas operaciones naturalizadas, con las mediaciones que atraviesan ese mundo y con la naturaleza de la mediación misma.

\section{Za abducción según Peirce}

¿Qué es la abducción? Me propongo contestar esta pregunta a partir del lugar estructural que ocupa la abducción en la semiótica de Charles S. Peirce, ya que este lugar es a la vez parte constituyente de su teoría y punto de acceso a la misma. Esto me permitirá explorarla tanto desde un enfoque intrínseco como extrínseco al autor. El corpus semiótico de Peirce puede ser entendido como lo que Eduardo Andión ha llamado "el último gran esfuerzo por una arquitectónica del conocimiento" (2011). Hay además varios referentes clásicos en relación al carácter arquitectónico del modelo triádico peirciano (véase, por ejemplo, Hookway, 1985; Anderson,1995 y Atkin, 2004). Imaginando la totalidad de la obra semiótica de Peirce como una arquitectónica, exploraré la posibilidad de entender la abducción misma como el punto de excepción fundacional que sostiene y a la vez trasciende dicha estructura.

15- Quiero apuntar que, mientra aquí he criticado la falta de diversidad de voces en las compilaciones sobre la pandemia Sopa de Wuhan y, en menor medida, Capitalismo y pandemia, anteriormente he rescatado los análisis de varios de sus autores en torno a la manera en que correlacionan el COVID-19 y ciertos efectos del capitalismo colonial, en particular, el cambio climático. Como he indicado anteriormente, estos aspectos contradictorios de las publicaciones son el tipo de contradicciones constitutivas con las que me interesa permanecer y entender, en lugar de descartar. Como he insistido apoyándome en Horkheimer, la contradicción tiene un valor central para la teoría crítica (2003, p. 240-1). En este caso específico, mientras que las publicaciones reproducen un sistema de legitimación académica que tiende a privilegiar voces masculinas, consagradas y metropolitanas, también posibilitan la crítica desde dentro de este mismo sistema. Operan como lo que Gayatri Spivak llamase una habilitación violentadora (1993, p. 44). 
La referencia -que también aplicó el lógico alemán Michael Hoffman (2001, p. 7)- a la obra de Peirce como una "arquitectónica" subraya su tendencia estructuralista (en contraste al posestructuralismo contemporáneo, al que referí en la introducción, asociado al giro lingüístico en el pensamiento Occidental y donde prevalece lo que Roland Barthes (1987) -y Umberto Eco (1984)- llamasen la "obra abierta"). El trabajo de Peirce coincide históricamente con la emergencia del estructuralismo europeo. Peirce comparte cierta sensibilidad con pensadores coetáneos, sensibilidad que puede describirse como una lógica diagramática. Peirce afirma que "El razonamiento diagramático es el único razonamiento realmente fértil. Si sólo los estudiosos de la lógica acogieran este método, ya no veríamos intentos de basar su ciencia en las frágiles fundaciones de la metafísica o de una psicología sin sustento en la teoría lógica; y pronto habría tal avance en la lógica que cada ciencia sentiría los beneficios de ello" (1994, vol. 4, p. 571). Queda clara la voluntad de Peirce de construir una arquitectónica del conocimiento capaz de superar una fundación metafísica. En este sentido, se puede aplicar a Peirce la crítica de Jacques Derrida a la creencia de discursos estructuralistas y post-estructuralistas de poder trascender un punto fundacional metafísico.

Derrida se refiere al lenguaje como la "estructura de estructuras" (1978, p. 293). Propone que una estructura está organizada en torno a un centro cuya función es organizar y delimitar su libre juego. Este centro es el punto ciego que opera en cualquier perspectiva ya que "constituye aquello dentro de la estructura que es la misma cosa que gobierna la estructura, a la vez que esquiva la estructuralidad". Para Derrida, la historia de la metafísica puede ser entendida como "una serie de substituciones de un centro por otro" y la ruptura en esta historia de substituciones sucesivas llegó "cuando se hizo necesario pensar la estructuralidad de la estructura... A partir de allí probablemente fue necesario comenzar a pensar... que no era un locus fijo sino una función". Derrida aclara que "este fue el momento en el cual el lenguaje invadió la problemática universal... cuando todo se hizo un sistema en donde el significado central, el significado original o trascendental nunca está absolutamente presente fuera de un sistema de diferencias". Esta característica lleva incluso a los discursos posestructuralistas que critican la metafísica a quedarse "atrapados en una suerte de círculo... [que] describe la forma de la relación entre la historia de la metafísica y la destrucción de la historia de la metafísica... No tenemos ningún lenguaje, ninguna sintaxis, ningún léxico, que sea ajeno a esta historia” (pp. 278-281). Es importante enfatizar que esta crítica a la metafísica Occidental es cierta solamente desde el propio Occidente. Como he sugerido con referencia a Barbero, Dussel, Mazrui y García Bravo, el desplazamiento del punto de enunciación quizás sí pueda ofrecer un lenguaje, sintaxis o léxico relativamente inéditos.

La tendencia diagramática en Peirce, su capacidad de visualizar sincrónicamente los distintos elementos involucrados en las relaciones lógicas, rinde cuenta de su voluntad estructuralista. Si pensamos en la obra de Peirce como una estructura, podemos pensar lo que Derrida llama el centro o significado trascendental como la piedra angular sobre la cual se yergue su edificio. Recordemos que el esfuerzo de Peirce por trascender "las frágiles fundaciones de la metafísica" está asociado a su interés por no basarse en "una psicología sin sustento en la teoría lógica" (1994, vol. 4, p. 571) y como parte de su esfuerzo sistemático por separar el entendimiento de la semiosis de lecturas psicologicistas de la misma. De tal modo, la teoría semiótica de Peirce describe procesos lógicos en la producción de sentido, pero no considera las instancias concretas que llevan a cabo dichos procesos lógicos. En otras palabras, excluye la noción de sujeto. El "interpretante" en Peirce se puede entender como una mediación cultural a través de la cual se activa la relación formal entre "representamen" y "objeto" 
para producir un significado socialmente convenido. Sin embargo, a diferencia de lo que ocurre en el trabajo de Charles Morris, este proceso en la diagramática de Peirce está desasociado de los sujetos que lo llevan a cabo. Morris (1985), sin embargo, incluye la instancia de los "interpretes", es decir, los agentes en el proceso semiótico.

La exclusión del sujeto en Peirce me interesa en tanto que la abducción está asociada a procesos que desde la teoría psicoanalítica podríamos llamar inconscientes y el inconsciente es la instancia fundamental en la definición contemporánea de sujeto. ${ }^{16}$ Como lo ilustra el psicoanalista francés Jacques Lacan en su texto "La instancia de la letra en el inconsciente o la razón desde Freud" (1958), al introducir la noción del inconsciente, Freud está declarando que el ser no es coextensivo con la consciencia. Argumenta Lacan que dicha afirmación pone en tela de juicio las fundaciones ontológicas y epistemológicas del pensamiento Occidental contemporáneo que desciende de René Descartes, ya que desestabiliza la máxima cogito ergo sum ("pienso, luego existo"). Dada la fusión del pensamiento con el ser implícita en la máxima cartesiana, una desestabilización del sujeto (del "existo") es necesariamente una desestabilización de la razón (del "pienso"). Por ello, Lacan considera que hasta que apareció la teoría freudiana, la razón era concebida como limitada a la conciencia y que, a partir de Freud, nuestra concepción de la razón debe superar los límites impuestos a ella desde el positivismo lógico.

El trabajo de Peirce trasciende el positivismo a la vez que se articula mediante herramientas afines al mismo, asociadas a su creencia en el progreso científico y a su intención de hacer de la filosofía una ciencia. Peirce declara que "sólo hay que dejar que las concepciones diagramáticas exactas, como aquellas de las matemáticas, tomen el lugar del vago discurso que ha prevalecido en la filosofía moderna... y ¿qué más se necesitará para hacer de la metafísica una ciencia?” (1994, vol. 8, p. 119). El pensamiento diagramático al que apela Peirce es el mismo que él realiza al representar las operaciones semióticas mediante esquemas triádicos, ya que dicho pensamiento consiste en "tratar la generalidad desde el punto de vista de la continuidad geométrica" (1994, vol. 6, p. 204).

La abducción es piedra angular en la teoría epistemológica de Peirce porque supera a la vez que está sometida al razonamiento diagramático que rige su filosofía. Además, la abducción se puede entender como piedra angular al ser el punto de origen del ámbito epistémico. Peirce se refiere a la lógica abductiva como "el método para obtener nuevas ideas" y escribe que "una abducción es Originaria en tanto es el único tipo de argumento que comienza una nueva idea" (1994, vol. 2, p. 4, 97). En otras palabras, la abducción es piedra angular en tanto participa en -pero también queda parcialmente excluida de- el sistema lógico de producción de significados que Peirce representa. Más que un razonamiento dado, la abducción en Peirce es aquello que inaugura la lógica. Para elaborar sobre este punto, se hace necesaria una visión panorámica de la obra del investigador en semiótica estadounidense y del lugar que ocupa en ésta la abducción.

Comienzo por aclarar que la semiótica de Peirce tiene implicaciones en ámbitos que rebasan la semiótica en su sentido estricto. Es decir, la teoría de Peirce abarca los ámbitos de la ontología (más puntualmente la fenomenología o lo que él llama "faneroscopía"), de la semiótica propiamente y de la epistemología (véase Parker, 1994). Formalmente, la abducción se inscribe en este último ámbito, aunque, como argumento, opera como piedra angular de la arquitectónica total de Peirce,

16- La analogía entre la abducción y su contraparte en el funcionamiento del aparato psíquico inconsciente es evocadora pero no exacta. Para Peirce, la abducción es una lógica de lo posible y de lo probable, en contraste a lo necesario. En cambio, el inconsciente, entendido en términos freudianos, es la encarnación misma de la necesidad que se impone al sujeto. 
incluyendo, sin lugar a dudas, la semiótica. Tradicionalmente, ontología, semiótica y epistemología son ámbitos que se estudian a partir de una oposición binaria: objeto versus sujeto en el caso de la ontología, significante versus significado en la semiología saussereana, y deducción versus inducción en la epistemología. En todos los ámbitos mencionados, el modelo de Peirce es triádico. Por ejemplo, la dualidad entre sujeto y objeto de la ontología se desestabiliza con su introducción del signo al estudio de este campo. Al respecto, el artista mexicano Chávez Mayol sostiene que el signo, al irrumpir en la continuidad sensible entre el yo y el mundo "instituye la diferencia" (2011). De manera análoga, se puede considerar a la abducción en el ámbito de la epistemología: la abducción como la lógica que instituye la razón. Es por su carácter fundacional que la abducción se asocia al surgimiento de nuevas hipótesis en la ciencia y a cambios paradigmáticos en la historia del pensamiento legalizado, y que se describe como la lógica propia del arte.

La abducción, a la vez que es punto de quiebre, está en relación de continuidad con la percepción. El principio de continuidad lógica o sinequismo que constituye uno de los pilares del modelo de Peirce contempla la continuidad entre abducción y percepción de la manera que relato a continuación: Ejemplificando con dibujos como aquél que, desde una perspectiva, parece gradas vistas desde arriba y, desde otra, gradas vistas desde abajo, Peirce explica cómo una línea puede aparecer como dos cosas distintas de acuerdo a la manera en que la clasifiquemos a nivel perceptual. Lo que denota la ilusión visual en tales casos es que "una cierta teoría de interpretación de la figura tiene toda la apariencia de estar dada en la percepción" ( $C P$ 5.183). Sin embargo, al cambiar nuestro juicio perceptivo y registrarse como otra cosa se "muestra que estos fenómenos son verdaderos enlaces conectivos entre abducciones y percepciones" (CP 5.183).

Como se puede apreciar, la lógica no binaria es característica del pensamiento peirciano. La doble valencia de la línea en el ejemplo de Peirce muestra cómo, bajo la misma lógica, la abducción, como he venido relatando, opera a la vez como punto de ruptura y tejido conectivo; del mismo modo también en que el signo, para Peirce es a la vez cosa (en el sentido de ser una cosa que representa otra cosa para alguien [CP 2.228]) y función (en el sentido de que cualquier cosa puede operar como signo pero ninguna lo es intrínsecamente). La lógica no binaria también es fundamental a la mecánica cuántica, la cual admite la adjudicación de más de una trayectoria al movimiento efectuado por una sola partícula. ${ }^{17}$ De igual modo, en matemáticas, la lógica difusa, también conocida como lógica borrosa, fundamental al desarrollo de la inteligencia artificial, no se rige bajo el principio binario de A o B sino que admite la posibilidad de A y B (véase Dubois y Prade, 1980). Finalmente, cabe señalar el parentesco de tales modos de indeterminación compleja y productiva con la teoría crítica: la teoría crítica no busca resolver ni esconder las contradicciones (lo cual es, por otra parte, el empuje central del pensamiento Ilustrado), sino que las acepta y trabaja con y a través de ellas. Así, por ejemplo, se alcanza mayor objetividad crítica aceptando nuestra historicidad y la de toda teoría en nuestro quehacer intelectual, para medir su impacto (del mismo modo que planteaba Gambini en relación a la física) y no negando o escondiendo dicho impacto. ${ }^{18}$ Todo esto, para insistir en que el principio de sinequismo de Peirce es enteramente compatible con la lectura de la abducción como punto de quiebre entre constructo teórico

17- Véase el recuento que hace Stephen Hawking de la dualidad onda/partícula según la visualización de Richard Philips Feynman en A Brief History of Time, (1988, p. 62). Véase también Aroch (2010, p. 65).

18- Gayatri Spivak distingue las teorías dogmáticas de las teorías críticas argumentando que estas últimas son las que reconocen los límites del conocimiento (1993, p. 27). 
y realidad representada. Pero, por encima de esto, está también el hecho de que la consistencia interna de la obra de Peirce no es lo que la legitima como teoría crítica, sino su potencial transformativo en el contexto presente. Además, como aclara Horkheimer, son los procesos sociales los que determinan la emergencia de nuevas tesis, no las contradicciones lógicas inmanentes de un sistema de pensamiento (pp. 229-30). Y es justo por esto último que resulta fundamental examinar los conceptos de Peirce más allá de la arquitectónica del propio pensador, tanto como rigurosamente desde dentro de la misma.

Al recuperar la abducción como punto fundacional del razonar, Peirce está contestando la visión reduccionista de la razón que impuso el positivismo lógico cuestionado por Lacan. No es casual que la abducción fuese entendida como una lógica válida durante el medioevo pero que se descartara a partir del Renacimiento y, aún con mayor fuerza, a partir de la Ilustración. No es casual, tampoco, que la reintroducción que hace Peirce de esta lógica descartada sea resistida. Entre aquellos que se resisten a la validación de la abducción se encuentra Hoffmann. Al preguntarse qué es lo "lógico" de la lógica abductiva, Hoffmann explora la aparente contradicción del uso que Peirce hace del término "lógica" para describir la abducción (1998). Mediante un procedimiento de análisis claro y riguroso, Hoffman se dedica a entender hasta qué punto puede considerarse que la abducción sea un tipo de razonamiento propiamente lógico. Las conclusiones de Hoffman son insatisfactorias y me parece que esto es resultado de que Hoffman se encierra en los términos propios de la arquitectónica de Peirce sin ver los puntos fundacionales de la misma. En otras palabras, aunque discursivamente cuestiona que la abducción "quepa" dentro del campo de la lógica, performáticamente lo acepta, ya que sólo utiliza elementos propios a una lógica lineal y de foco estrecho para tratar de entenderla.

Como he indicado, la obra de Peirce es un sistema cerrado, lo cual es claramente observable en la serie de diagramas que constituyen las interrelaciones de su modelo semiótico. Este modelo funciona, como cualquier modelo o teoría, al seleccionar, abstraer, y rearticular elementos de la realidad. Específicamente, lo que se aísla y examina en el modelo semiótico de Peirce son las interrelaciones de los procesos lógicos de generación de significado de su soporte pragmático, es decir, de los sujetos que los llevan a cabo. El proceder de Hoffmann implica una cierta literalidad en la cual se toma al pie de la letra el modelo y lo examina en sus propios términos, pero olvidando la piedra angular, es decir, olvidando que es un modelo. Anteriormente, he citado a Culler para entender la ideología como la naturalización de una narrativa. A partir de ello, la lectura que hace Hoffmann de Peirce puede considerarse como eminentemente ideológica. Sin embargo, como he propuesto en relación a Adorno y Horkheimer, no por ello deja de ser científica. En otras palabras, las postulaciones de Hoffman caen dentro de la ciencia tradicional al ofrecer postulados correctos pero ciegos (Horkheimer, 2003, p. 258).

La abducción como falla en el modelo de Peirce, devela una discontinuidad entre la totalidad de su representación teórica y la realidad de la que rinde cuenta. Por ello, no se trata tanto de una falla en el sentido moral -un "error"-, como sugiere Hoffmann, sino de una falla en el sentido topográfico. Con el uso de este término remito al quehacer cotidiano de Peirce como cartógrafo y pongo en primer plano el campo de incidencia mutua entre sus paisajes teóricos y aquellos de índole geográfica. Pienso la acepción de "falla" desde la topografía a partir de una metáfora de Chávez Mayol, para quien la abducción es "el descubrimiento íntimo de lo inefable, de una fisura en la lectura cotidiana del mundo" (2011). Como modo de razonamiento, la abducción devela esa fisura. Como signo en el sistema representacional que es la teoría de Peirce, la abducción emerge como índice, marcando el punto de (des)encuentro, entre la representación particular y el ámbito de realidad que le excede. La fisura en 
la lectura cotidiana del mundo abre la grieta de lo que Chávez Mayol llamase "el universo más acá de lo pensable" (2011), mientras que la superficie sobre la cual se abre esa grieta estaría vinculada al pensamiento mismo. Por ello, la abducción es el salto cualitativo entre lo impensado y la emergencia inmediata del conocimiento. Ese salto articula al sujeto como sujeto, es decir como instancia donde opera un sentido articulado en los límites de lo inefable.

Pienso también en la diferenciación qué, siguiendo a Ducrot, hace el antropólogo y comunicólogo mexicano Eduardo Andión entre "significación" como "el significado semántico" y "sentido" como "el significado pragmático" que acontece en el tiempo y en contextos sociales concretos (2007, p. 20). Así, por ejemplo, en la sección anterior vimos cómo la proyección quincuncial de Peirce produce cierta significación en relación a la realidad que representa, pero esa significación sólo adquiere sentido social al ejercerse; al apreciarse en términos de su contexto histórico. Es a través de la recepción de Peirce en Peters y a partir de nuestra propia mirada retrospectiva de esta historia que el mapa de Peirce se juega claramente como un gesto político, contestatario de la ideología dominante. De igual forma, la abducción como el pegamento fundacional que da sentido a la arquitectónica de Peirce más allá de sus operaciones lógicas internas es un referente vital para repensar el mundo tras el COVID-19, pandemia que abre un espacio, una fisura para conceptualizar, comunicar y habitar nuestro lugar en el planeta de otro modo.

\section{Cierre y aperturas}

La fisura es, entonces, índice del punto de cierre de un sistema y, a la vez, sitio de su apertura potencial a configuraciones inimaginadas. La mirada al concepto de abducción desde el Sur Global en tiempos de COVID-19 nos ha permitido entenderla como fisura fundacional de la arquitectónica peirciana. Es en esta capacidad que la abducción ofrece posibilidades tanto críticas como inventivas a los modos vigentes de habitar nuestros cuerpos y nuestros mundos biológicos, ecológicos, ideológicos, comunicativos, semióticos y sociales. Siendo esa fisura herida, siendo marca de un cierre imperfecto, atender a cómo opera esa fisura en nuestros modelos actuales para habitar y teorizar el mundo nos da pautas importantes para la crítica de los mismos, para la crítica de aquellos aspectos del presente que están por caducar. Siendo esa fisura fundacional a la vez el lugar de posibilidad por excelencia, rescatar el pensamiento abductivo abre campo a la inventiva lúdica necesaria para comenzar a trazar nuevos mapas para un mundo en reconfiguración. De estos modos, hemos vuelto la mirada al pasado peirciano para construir futuro y también hemos pensado a Peirce como fisura que forma parte de la hegemonía teórica de Occidente y, a la vez, la fragmenta y desplaza.

En 1949 Theodor W. Adorno hizo el famoso pronunciamiento de que escribir poesía después de Auschwitz era un acto de barbarie (1962, p. 29). Ante la coyuntura actual, quizás podemos ir trazando un mapa nocturno para ir poniendo el trauma en palabras, ir digiriendo el golpe efectuado sobre nuestros cuerpos individuales y colectivos, un golpe que, como sugiere Dussel, no por provenir de un virus deja de estar histórica-, semiótica- e ideológicamente constituido de acuerdo a intereses políticos y económicos específicos. Es por ello que la reinvención de lo nuevo a través de la palabra quizás pueda efectuarse con mayor éxito hoy desde la periferia, desde un lugar otro en el que, como planteara Martín Barbero, lo enunciado es correlativo al desplazamiento del lugar y las formas de enunciación. 
Otro planteamiento sugestivo y bastante novedoso que hace Dussel en relación a la pandemia es reclamar el concepto de vida para la izquierda (2020b). Ya Judith Butler había argumentado la necesidad de reapropiarnos la vida como valor, redefiniendo una maniquea concepción de la vida que ha permitido, en el contexto de la discusión sobre el aborto, su propiedad exclusiva por parte del movimiento "pro-vida" (2009). Pero Dussel lleva este esfuerzo por reivindicar la vida a nivel macroestructural y propone, a contracorriente de las éticas de los valores, incluso las marxistas, que la vida ha de reivindicarse como el fundamento mismo de la ética (2020b, min. 30).

Para Dussel, lo que anuncia el virus no es el fin de la vida sobre el planeta, sino el fin de la modernidad capitalista colonial (2020a). En este sentido, el planteamiento de Dussel es contrario a la declaración de Frederic Jameson de que en el capitalismo tardío es más fácil imaginar el fin del mundo que el fin del propio capitalismo (2003). El COVID-19 llega a mostrar cómo nuestro mundo es el capitalismo, cómo el virus emerge por las condiciones materiales de producción del capitalismo moderno colonial y cómo el fin del capitalismo desencadena el fin del mundo, tal como lo conocemos.

Tal es el efecto no sólo material sino semiótico del virus, tal su manera de jaquear las historias naturalizadas que nos hacíamos de las cosas en el mundo que, por ejemplo, el movimiento \#BlackLivesMatter se desencadena a partir de las condiciones de desigualdad racial en EEUU que el virus expuso de manera más radical que nunca, su reforzamiento ya insostenible de las contradicciones de clase al centro del imperio contemporáneo. El comunicólogo André Dorcé también ha demostrado cómo, en el contexto mexicano, la pandemia exacerba las diferencias que operan a través de un discurso racializado que se recrudece como campo de batalla en el contexto de la crisis sanitaria (2021). Si el COVID-19 está jaqueando cierta semiosis establecida del mundo es no sólo porque la semiótica participa de la construcción material del mundo, sino también porque existe un correlato silencioso: el mismo virus es a la vez evento y signo, función e información biológica, suceso natural-, histórica- y culturalmente condicionado por nuestros modos de producción material e ideológica durante más de cinco siglos.

Por ello, Dussel -y Butler- han argumentado la necesidad de recuperar para los movimientos emancipatorios la vida como valor fundacional. A lo largo de este artículo he sugerido, de manera implícita, hacer lo mismo con la idea de la "mundialización" que describe la teórica india Gayatri Spivak (1985). Si la mundialización es el acto de nombrar el mundo a imagen y semejanza del capital colonialista moderno, propongo que hoy volvamos a trazar el mapa de esa historia desde otro lugar, desde el inconsciente constitutivo de dicha trayectoria vista desde el Sur Global, desde la cara oculta de la modernidad que ahora emerge entre las fisuras abiertas por un virus cuya existencia depende de poder seguir suplantando la información que configura nuestros cuerpos.

En dicho esfuerzo, revisitar a Peirce como geodesta e investigador en semiótica resulta productivo. La teoría de Peirce opera como teoría crítica en tanto desestructura la ideología reinante de su época y aun hoy en día y desde la periferia global sostiene un potencial transformador. Como bien anunciara Horkheimer en el texto fundacional de la Escuela de Frankfurt, conformarse en que pensar es fijo y aislado es renunciar "a la esencia misma del pensar" (2003, p. 271). Por ello, no he utilizado las propuestas de Peirce de manera meramente deductiva, sino que lo he posicionado en una relación de correspondencia con el contexto que busqué iluminar a través suyo. En este sentido, he seguido la metodología de Mieke Bal, para quien los objetos de análisis pueden ser al mismo tiempo "objetos teóricos" que tienen la capacidad de interrogar a la teoría a la que son sometidos en términos de igualdad. Peirce 
ofrece herramientas insospechadas para la construcción de otros futuros posibles ante el derrumbe de sentido que se vino con la pandemia, mientras que la experiencia de la misma desde el Sur global nos permite interpelar al teórico estadounidense de maneras inusitadas. Esta interrogación recíproca, esta apertura crítica, es lo que abre campo fértil al potencial transformador de la teoría de Peirce.

\section{Referencias}

Adorno, T.W. (1962). Prismas. Crítica de la cultura y la sociedad (Sacristán, trad.). Arial.

Adorno, T. W. (1983). Negative Dialectics (E. B. Ashton, trad.). Continuum.

Adorno, T. W. (1984). Dialéctica negativa (J. M. Ripalda, trad.). Taurus Ediciones.

Adorno, T. W. y M. Horkheimer (2007). Dialéctica de la ilustración (J. Chamorro Mielke, trad.). Akal. Agencia EFE (1 de octubre de 2020). La OMS asocia la pandemia al cambio climático. EFE Verde.https:// www.efeverde.com/noticias/oms-asocia-pandemia-cambio-climatico-cuestion-tiempo/

Amadeo, P. (ed). (2020). Sopa de Wuhan. ASPO.

Anderson, D. (1995). The Strands of the System. Purdue University Press.

Andión, E., Lizarazo D. y Zires M. (2007) Interpretaciones icónicas. Siglo XXI.

Andión, E. (18 de octubre de 2011). Cátedra Seminea. Cenart.

Aroch Fugellie, P. (2010). Movement and the Paradox of Resistance. Cosmos and History: The Journal of Natural and Social Philosophy, 6 (2) 55-70.

Aroch Fugellie, P. (2015). Promesas irrealizadas: El sujeto del discurso poscolonial y la nueva división internacional del trabajo. Siglo XXI.

Atkin, A. (2004). Charles Sanders Peirce: Architectonic Philosophy. Internet Encyclopedia of Philosophy. https://iep.utm.edu/peircear/

Bal, M. (2002). Travelling Concepts in the Humanities: A Rough Guide. University of Toronto Press.

Barthes, R. (1987) La muerte del autor. El susurro del lenguaje. Paidós, 65-71.

Berardi, F. B. Más allá del colapso: Tres meditaciones sobre las condiciones resultantes posibles. Capitalismo y Pandemia (F. García ed.). Filosofía libre, 38-44.

Burch, R. (2021). Charles Sanders Peirce. The Stanford Encyclopedia of Philosophy. Stanford. https:// plato.stanford.edu/archives/spr2021/entries/peirce/

Butler, J. (2009). Frames of War. Verso.

Butler, J. (2020). El capitalismo tiene sus límites. Sopa de Wuhan (P. Amadeo, ed). ASPO, 59-66.

Chávez Mayol, H. (18 de octubre de 2011) Cátedra Seminea. Cenart.

Culler, J. (1973). Structure of Ideology. New Literary History, 4 (3), 471-482.

Derrida, J. (1978). Structure, Sign, and Play in the Discourse of the Human Sciences. En Writing and Difference, (pp. 278-293). Routledge.

Dorcé, A. (2021). Nuevos horizontes de la corrección política en México. Comunicar, (3).

Dubois, D., y H. M. Prade (1980). Fuzzy Sets and Systems: Theory an Applications. Academic Press.

Dussel, E. (2020a). Cuando la naturaleza jaquea la orgullosa modernidad. Capitalismo y pandemia (pp. 87-90). Filosofía libre. 
Dussel, E. (9 de abril del 2020b). La pandemia con Enrique Dussel. Ética y política. Aristegui Noticias. https://www.youtube.com/watch?v=ILuu3lYWFAg

Eco, U. (1984). Obra abierta. Planeta-Agostini.

Einstein, A. (1920). Relativity: The Special and General Theory. Methuen.

Fann, K. T. (1970). Peirce's Theory of Abduction. Springer.

Ferguson, J. (2006). Global Shadows: Africa in the Neoliberal World Order, Duke.

Gabriel, M. (2020). El virus, el sistema letal y algunas pistas. Sopa de Wuhan (P. Amadeo, ed). ASPO, $129-134$.

Galindo, M. (2020). Desobediencia, por tu culpa voy a sobrevivir. Sopa de Wuhan (P. Amadeo, ed). ASPO, 119-128.

García Bravo, H. (2020). Si el capitalismo es la enfermedad ¿cuál es la cura? Memoria, 274 (2). http:// revistamemoria.mx

Gambini, R. (1999). Física y realidad. En Certidumbres, incertidumbres, caos: Reflexiones en torno a la ciencia contemporánea. La Vasija, 15-48.

Gumucio, A. (2017). En el abismo de las preguntas. En De los medios a las mediaciones de Jesús Martín Barbero (Moragas, Terrón y Rincón, eds.; pp. 124-128). InCom-UAB.

Hall, S. (1997). Representation, Meaning and Language. En Representation: Cultural Representations and Signifying Practices. Sage, 15-29.

Han, B.C. (2020). La emergencia viral y el mundo de mañana. Sopa de Wuhan (P. Amadeo, ed). ASPO, 97-112.

Harvey, D. Política anticapitalista en tiempos de coronavirus. Sopa de Wuhan (P. Amadeo, ed). ASPO, 79-96.

Hawking, S. A Brief History of Time (1988). Bantam Books.

Hoffmann, M. (1998). ¿Hay una 'lógica' de la abducción? Universidad de Navarra. https://www.unav. es/gep/AN/Hoffmann.html

Hookway, C. J. (1985). Peirce. Routledge y Kegan Paul.

Horkheimer, M. (2003). “Teoría tradicional y teoría crítica”. En Teoría crítica (E. Albizu y C. Luis, trads.). Amorrortu Editores, 223-271.

Horta, J., Paulín G. y Flores G. (2019). Sociosemiótica y cultura. UNAM.

Jameson, F. (2003). Future City. New Left Review, (21).

Karmy Bolton, R. (2020). La mutación china (O sobre la desweberianización del capitalismo). Capitalismo y Pandemia (F. García ed.). Filosofía libre, 45-50.

Lacan, J. (1988). The Purloined Letter. Purloined Poe (Muller, ed.) Johns Hopkins.

Lacan, J. (2004). The Instance of the Letter in the Unconscious, or Reason Since Freud. En Écrits: A Selection (B. Fink, trad.; pp.413-441). W.W. Norton and Company.

Lambertini, M., Maruma Mrema, E., y Neira, M. (17 de junio de 2021). Coronavirus is a warning to us to mend our broken relationship with nature. The Guardian. https://www.theguardian.com/ commentisfree/2020/jun/17/coronavirus-warning-broken-relationship-nature

Lazzarato, M. (2020) ¡Es el capitalismo, estúpido! Capitalismo y Pandemia (F. García ed.). Filo sofía libre, 91-112.

Martín Barbero, J. (2003). De los medios a las mediaciones. Andrés Bello. 
Mazrui, A. (1986). The Africans: A Triple Heritage. Brown \& Company.

Miller, T. (2021). A COVID Character, A Better World. Rutgers University Press.

Morris, C. (1985). Fundamentos de la teoría de los signos. Paidós.

Nietzsche, F. (2002). Beyond Good and Evil (Horstmann y Norman, eds.). Cambridge.

Parker, K. Peirce's Semeiotic and Ontology. Transactions of the Charles S. Peirce Society, 30 (1), 51-75.

Peirce, C. S., Hartshorne, C., Weiss, P., y Burks, A. W. (1965). Collected papers of Charles Sanders Peirce. Belknap Press de Harvard University Press.

Randall, J. (1989). Teleology and the Autonomy of the Semiosis Process. The Peirce Group's Arisbe. https://arisbe.sitehost.iu.edu/menu/library/aboutcsp/ransdell/AUTONOMY.HTM

Roy, A. (2020). La pandemia es un portal. Capitalismo y Pandemia (F. García ed.). Filosofía libre, 51-60.

Seleme, F. Combatiendo al virus y al capital. Capitalismo y Pandemia (F. García ed.). Filosofía libre, 83-86.

Shome, R., y Hedge, R.S. (2002). Postcolonial Approaches to Communication: Charting the Terrain, Engaging the Intersections. Communication Theory, 12 (3), 249-270. https://doi.org/10.1111/j.1468-2885.2002.tb00269.x

Spivak, G. (1985). The Rani of Sirmur: An Essay in Reading the Archives. History and Theory, 24 (3), 247-272. http://www.jstor.org/stable/2505169

Spivak, G. (1993). Outside in the Teaching Machine. Routledge.

Žižek, S. (2020). El coronavirus es un golpe al capitalismo a lo Kill Bill. Sopa de Wuhan (Amadeo, ed). ASPO, 21-28. 